\title{
Revised Taxonomy of the Class Mollicutes: Proposed Elevation of a Monophyletic Cluster of Arthropod-Associated Mollicutes to Ordinal Rank (Entomoplasmatales ord. nov.), with Provision for Familial Rank To Separate Species with Nonhelical Morphology (Entomoplasmataceae fam. nov.) from Helical Species (Spiroplasmataceae), and Emended Descriptions of the Order Mycoplasmatales, Family Mycoplasmataceae
}

JOSEPH G. TULLY, ${ }^{1 *}$ JOSEPH M. BOVÉ, ${ }^{2}$ FRÉDÉRIC LAIGRET, ${ }^{2}$ AND ROBERT F. WHITCOMB ${ }^{3}$

Mycoplasma Section, Frederick Cancer Research and Development Center, National Institute of Allergy and Infectious Diseases, Frederick, Maryland 21702 ${ }^{1}$; Laboratoire de Biologie Cellulaire et Moléculaire, Institut National de la Recherche Agronomique and University of Bordeaux II, 33883 Villenave-d'Ornon Cedex, France $^{2}$; and Insect Biocontrol Laboratory, U.S. Department of Agriculture, Beltsville, Maryland 20705

On the basis of recent phylogenetic studies of 47 species within the class Mollicutes and recent molecular and physiologic findings that distinguish a new group of non-sterol-requiring insect and plant mollicutes from Acholeplasma species, we propose a revised taxonomy of the class Mollicutes. Order I (Mycoplasmatales) is retained as described earlier (S. Razin and E. A. Freundt, p. 740-742, in N. R. Krieg and J. G. Holt, ed., Bergey's Manual of Systematic Bacteriology, vol. 1, 1984), with provision for a single family (Mycoplasmataceae) and two genera (Mycoplasma and Ureaplasma) for classification of sterol-requiring mollicutes primarily associated with vertebrates. Emended descriptions of the order and family for the above taxa are hereby included. Proposed order II (Entomoplasmatales ord. nov.) contains subtaxa for either nonhelical (Entomoplasmataceae fam. nov.) or helical (Spiroplasmataceae) mollicutes; the latter family is hereby transferred from the order Mycoplasmatales. The new order and family permit designation and classification of a monophyletic cluster of mollicute strains associated primarily with arthropods. It is proposed that nonhelical, sterolrequiring insect and plant mollicutes previously designated Mycoplasma ellychniae (Tully et al., 1989), Mycoplasma melaleucae (Tully et al., 1990), Mycoplasma somnilux (Williamson et al., 1990), Mycoplasma luminosum (Williamson et al., 1990), and Mycoplasma lucivorax (Williamson et al., 1990) be transferred to Entomoplasma gen. nov., family Entomoplasmataceae fam. nov., as Entomoplasma ellychniae comb. nov., Entomoplasma melaleucae comb. nov., Entomoplasma somnilux comb. nov, Entomoplasma luminosum comb. nov., and Entomoplasma lucivorax comb. nov. Furthermore, the genus Mesoplasma gen. nov. within the family Entomoplasmataceae fam. nov. is proposed for four non-sterol-requiring insect and plant mollicutes. This designation requires the transfer of Acholeplasma florum (McCoy et al., 1984), Acholeplasma entomophilum (Tully et al., 1988), Acholeplasma seiffertii (Bonnet et al., 1991), and Mycoplasma lactucae (Rose et al., 1990) to Mesoplasma florum comb. nov., Mesoplasma entomophilum comb. nov., Mesoplasma seiffertii comb. nov., and Mesoplasma lactucae comb. nov., respectively. Previously established orders Acholeplasmatales and Anaeroplasmatales within the class Mollicutes are designated orders III and IV, respectively, in the proposed revision. Classification and characteristics of lower taxa within these two orders remain as previously given. The proposal outlined here does not consider the large cluster of nonculturable, arthropod-associated, plant-pathogenic mollicutes ("mycoplasma-like organisms") recently shown to be more closely related to members of the order Acholeplasmatales.

The order Mycoplasmatales, first proposed in 1955 by Freundt (11), was later incorporated into the joint taxonomic proposals of Edward and Freundt in 1967 (9) to classify sterol-requiring, wall-less prokaryotes in the class Mollicutes (26). In these early endeavors, the single order encompassed a small cluster of about 12 serologically distinct

\footnotetext{
${ }^{*}$ Corresponding author.
}

species. It soon became apparent that a number of newly described species in the genus Mycoplasma did not require sterols or cholesterol for growth, and subsequent proposals were made to separate these organisms into a new family (Acholeplasmataceae) and genus (Acholeplasma) within the order Mycoplasmatales $(10,39)$. By 1983, fundamental alterations in the perception of acholeplasma ecology had occurred, including observations that the organisms were commensals in a variety of animal hosts and could be 
isolated from insects and plant surfaces $(8,20,35,39,40)$. These and other major distinctions, particularly data showing that Acholeplasma species had twice the genome size (1,500 kbp) of Mycoplasma species, were used in a 1984 proposal that elevated the family Acholeplasmataceae to ordinal rank (order II, Acholeplasmatales) within the class Mollicutes (12). Later, a cluster of strictly anaerobic anaeroplasmas from the rumens of bovine and ovine hosts were raised to ordinal rank (order III, Anaeroplasmatales) within the class (29).

The taxonomic characterization and description of Spiroplasma citri in 1973 (32), the first helical, sterol-requiring mollicute of plant and/or arthropod origin, caused certain classification problems at higher taxonomic levels. The morphology of the organism was clearly different from that of all other known mollicutes, and while the helical organisms required cholesterol, their $1,500-\mathrm{kbp}$ genomes were twice the size of those of other species of sterol-requiring mollicutes. Eventually, $S$. citri and other species in the genus Spiroplasma were elevated (34) to a family (Spiroplasmataceae) within the order Mycoplasmatales. Although many new spiroplasmas have been subsequently discovered $(43,53)$, all have been shown to be associated with arthropods.

While higher classification of the spiroplasmas may have been a minor dilemma, it soon became apparent that other newly isolated plant or insect mollicutes presented much more serious problems in classification. The tropical flower isolates described in 1979 by McCoy and associates (20) were the first to undergo extensive characterization. Three serologically related strains (L1, GF1, and PP2) appeared to possess most of the properties of acholeplasmas, including rapid and extensive growth in broth medium at a temperature optimum of about $30^{\circ} \mathrm{C}$. Despite repeated testing, these strains could not be grown in medium devoid of cholesterol or serum. However, it was eventually shown that growth did occur in serum- or cholesterol-free media containing $0.04 \%$ Tween 80 (polyoxyethylene sorbitan) (40). Since these flower-associated strains apparently grew in the absence of serum or cholesterol, they were named Acholeplasma florum (18). Two additional serologically distinct species, again of insect or plant origin and with similar growth properties, were described more recently as Acholeplasma entomophilum (42) and Acholeplasma seiffertii (1).

The early studies of $A$. florum prompted efforts to understand the ecology of these plant-derived, nonhelical mollicutes. Subsequent studies of numerous nonhelical mollicutes, isolated by Clark and Whitcomb $(4,5)$ from insects collected over a wide geographical region in the United States, indicated that these organisms were common in the gut or hemolymph of these hosts. These observations not only provided the first evidence that nonhelical, non-sterolrequiring mollicutes occur in arthropods but offered a ready explanation for their presence on plant surfaces. From this collection of mollicutes, an additional 13 uncharacterized plant and insect isolates, representing at least seven putative species, have now been found to possess similar features and to show sustained growth in serum-free media only when supplemented with $0.04 \%$ Tween 80 (47).

While the response to Tween 80 suggested that the insect and plant isolates were distinct from classic acholeplasmas, the first substantial evidence of major differences came from a phylogenetic analysis of 47 mollicute species (or putative species) by Weisburg and colleagues (49). In this comparative study of $16 \mathrm{~S}$ rRNA sequences, both $A$. entomophilum and $A$. florum were shown to belong to the so-called "spiro- plasma/mycoides" group, a cluster of helical and nonhelical sterol-requiring organisms phylogenetically distinct not only from members of the orders Acholeplasmatales and Anaeroplasmatales but also from the vast majority of members of the family Mycoplasmataceae.

More recently, additional molecular distinctions between the non-sterol-requiring insect- or plant-derived strains and classic acholeplasmas have been documented. $A$. florum has been shown to possess a gene coding for one of the components (enzyme II) of a phosphoenolpyruvate-dependent sugar-phosphotransferase system and to utilize UGA as a tryptophan codon $(21,22)$. A functional phosphotransferase system(s) appears to be absent in Acholeplasma spp. and in some nonfermentative Mycoplasma species but is present in Spiroplasma spp. and fermentative Mycoplasma species (3, $37,38)$. Likewise, the use of the UGA codon as a tryptophan signal is characteristic of Mycoplasma and Spiroplasma species $(27,54)$. In contrast, Acholeplasma species utilize the UGA codon as a stop signal (36). Major differences in the genome size among organisms in each of the two groups have also been disclosed recently. Data obtained by pulsedfield gel electrophoresis show that $A$. florum and other similar insect- or plant-derived strains have genome sizes in the range of 860 to $1,100 \mathrm{kbp}(570$ to $730 \mathrm{MDa})(2,25)$. In contrast, classic Acholeplasma species have genomes of 1,500 to $1,600 \mathrm{kbp}(2,24,28)$. Thus, genome size, UGA codon usage, presence of a phosphotransferase system enzyme II, and 16S rRNA sequences of the new insect and plant mollicutes clearly imply that they have greater affinities to members of the order Mycoplasmatales than to members of the order Acholeplasmatales.

The sterol-Tween 80 test system described initially for $A$. florum $(18,40)$ and subsequently applied to other insect and plant mollicutes $(1,42,44,45,52)$ provides a consistent phenotypic marker for identification of strains that are capable of growing in the presence of $0.04 \%$ Tween 80 . A simplified method for testing sterol requirements, including measuring growth promotion with Tween 80 , has recently been proposed (31).

On the basis of the above observations, we offer the following proposals for revision in the taxonomy of the class Mollicutes (Table 1).

Proposal for Entomoplasma gen. nov. for sterol-requiring mollicutes of insect and/or plant origin. We propose that five species of sterol-requiring mollicutes of insect or plant origin currently assigned to the genus Mycoplasma be transferred to the genus Entomoplasma gen. nov. These include Entomoplasma ellychniae comb. nov. (Tully et al., 1989), Entomoplasma melaleucae comb. nov. (Tully et al., 1990), Entomoplasma somnilux comb. nov. (Williamson et al., 1990), Entomoplasma luminosum comb. nov. (Williamson et al., 1990), and Entomoplasma lucivorax comb. nov. (Williamson et al., 1990).

The five species in the genus have guanine-plus-cytosine DNA contents of 27 to $29 \mathrm{~mol} \%$ and genome sizes ranging from 790 to $1,140 \mathrm{kbp}$. The organisms require cholesterol or serum for growth and do not show sustained growth in serum-free or cholesterol-free media when supplemented with 0.01 to $0.04 \%$ Tween 80 . The five species are serologically distinct from each other and from all currently recognized species in the genus Mycoplasma. Organisms currently being assigned to the new genus grow over a temperature range of 10 to $32^{\circ} \mathrm{C}$, with optimum growth occurring at $30^{\circ} \mathrm{C}$. Growth is not apparent at $37^{\circ} \mathrm{C}$, the optimum growth temperature for most members of the genus Mycoplasma. All currently assigned species were isolated 
TABLE 1. Proposed taxonomy and characteristics of members of the class Mollicutes

\begin{tabular}{|c|c|c|c|c|c|c|}
\hline Classification & $\begin{array}{l}\text { No. of } \\
\text { recognized } \\
\text { species }\end{array}$ & $\begin{array}{l}\text { Guanine- } \\
\text { plus-cytosine } \\
\text { content } \\
\text { (mol\%) }\end{array}$ & $\begin{array}{l}\text { Genome } \\
\text { size (kbp) }\end{array}$ & $\begin{array}{c}\text { Cholesterol } \\
\text { require- } \\
\text { ment }\end{array}$ & Habitat & Other distinctive features \\
\hline \multicolumn{7}{|l|}{$\begin{array}{l}\text { Order I, Mycoplasmatales, family I, } \\
\text { Mycoplasmataceae }\end{array}$} \\
\hline Genus I, Mycoplasma & 85 & $23-40$ & $600-1,350$ & Yes & Humans, animals & $\begin{array}{l}\text { Optimum growth usually at } \\
37^{\circ} \mathrm{C}\end{array}$ \\
\hline Genus II, Ureaplasma & 5 & $27-30$ & $760-1,170$ & Yes & Humans, animals & Urea hydrolysis \\
\hline \multicolumn{7}{|l|}{ Order II, Entomoplasmatales } \\
\hline \multicolumn{7}{|l|}{ Family I, Entomoplasmataceae } \\
\hline Genus I, Entomoplasma & 5 & $27-29$ & $790-1,140$ & Yes & Insects, plants & Optimum growth, $30^{\circ} \mathrm{C}$ \\
\hline Genus II, Mesoplasma & 4 & $27-30$ & $870-1,100$ & No & Insects, plants & $\begin{array}{l}\text { Optimum growth, } 30^{\circ} \mathrm{C} \\
\text { sustained growth in se- } \\
\text { rum-free medium only } \\
\text { with } 0.04 \% \text { Tween } 80\end{array}$ \\
\hline $\begin{array}{l}\text { Family II, Spiroplasmataceae, } \\
\text { Genus I, Spiroplasma }\end{array}$ & 11 & $25-30$ & $940-2,200$ & Yes & Insects, plants & $\begin{array}{l}\text { Helical filaments; optimum } \\
\text { growth at } 30-37^{\circ} \mathrm{C}\end{array}$ \\
\hline $\begin{array}{l}\text { Order III, Acholeplasmatales, fam- } \\
\text { ily I, Acholeplasmataceae, genus } \\
\text { I, Acholeplasma }\end{array}$ & 9 & $26-36$ & $1,500-1,650$ & No & $\begin{array}{l}\text { Animals, some plants } \\
\text { and insects }\end{array}$ & $\begin{array}{l}\text { Optimum growth at } \\
30-37^{\circ} \mathrm{C}\end{array}$ \\
\hline \multicolumn{7}{|l|}{$\begin{array}{l}\text { Order IV, Anaeroplasmatales, fam- } \\
\text { ily I, Anaeroplasmataceae }\end{array}$} \\
\hline Genus I, Anaeroplasma & 4 & $29-34$ & $1,500-1,600$ & Yes & $\begin{array}{l}\text { Bovine or ovine } \\
\text { rumen }\end{array}$ & Oxygen-sensitive anaerobes \\
\hline Genus II, Asteroleplasma & 1 & 40 & 1,500 & No & $\begin{array}{l}\text { Bovine or ovine } \\
\text { rumen }\end{array}$ & Oxygen-sensitive anaerobes \\
\hline
\end{tabular}

from insects or plant surfaces where they were presumably deposited by insects. We propose the name Entomoplasma (En.to.mo'plas.ma. Gr. n. entomon, insect; Gr. neut. n. plasma, something formed or molded, a form; M.L. neut. n. Entomoplasma, name intended to show association with insects). The type species is Entomoplasma ellychniae (Tully, Rose, Hackett, Whitcomb, Carle, Bové, Colflesh, and Williamson, 1989).

The characteristics of the new genus and species are as described above and in previously published descriptions. Established type strains from earlier descriptions (E. ellychniae ELCN-1 ${ }^{\mathrm{T}}$, E. melaleucae $\mathrm{M1}^{\mathrm{T}}$, E. somnilux PYAN-1 ${ }^{\mathrm{T}}$, E. luminosum PIMN-1 ${ }^{\mathrm{T}}$, and E. lucivorax $\mathrm{PIPN}-2^{\mathrm{T}}$ ) are retained.

Proposal for Mesoplasma gen. nov. for non-sterol-requiring mollicutes of insect and plant origin. Three non-sterol-requiring species of insect or plant origin currently assigned to the genus Acholeplasma, and a single species of plant origin (Mycoplasma lactucae) (30) recently shown to grow in $0.04 \%$ Tween 80 -supplemented serum-free media (31), are hereby transferred to Mesoplasma gen. nov. These include Mesoplasma florum comb. nov. (McCoy et al., 1984), $\mathrm{Me}$ soplasma entomophilum comb. nov. (Tully et al., 1988), Mesoplasma seiffertii comb. nov. (Bonnet et al., 1991), and Mesoplasma lactucae comb. nov. (Rose et al., 1990), with their respective type strains retained as previously established (Mesoplasma florum $\mathrm{LI}^{\mathrm{T}}$, Mesoplasma entomophilum $\mathrm{TAC}^{\mathrm{T}}$, Mesoplasma seiffertii $\mathrm{F}^{\mathrm{T}}$, and Mesoplasma lactucae $831-\mathrm{C} 4^{\mathrm{T}}$ ).

The four species in the genus have guanine-plus-cytosine DNA contents of 27 to $30 \mathrm{~mol} \%$ and genome sizes ranging from 860 to $1,100 \mathrm{kbp}$. Organisms utilize the UGA codon as a tryptophan signal. Neither serum nor cholesterol is required for growth, but organisms show sustained growth in serum-free or cholesterol-free media supplemented with $0.04 \%$ Tween 80 . Organisms grow over a temperature range of 18 to $37^{\circ} \mathrm{C}$, with optimum growth occurring at 28 to $30^{\circ} \mathrm{C}$. The five species are serologically distinct from each other and from all currently defined species in the genus $\mathrm{Myco}$ plasma or the genus Entomoplasma, gen. nov. For these organisms, we propose the genus name Mesoplasma (Me.so'plas.ma. Gr. n. meso, middle; Gr. neut. n. plasma, something formed or molded, a form; M.L. neut. n. Mesoplasma, middle form, name intended to denote a middle position with respect to sterol or cholesterol requirement). The type species is Mesoplasma florum (McCoy, Basham, Tully, Rose, Carle, and Bové 1984). The characteristics of the new genus and species are as described above.

Elevation of Entomoplasma to family rank, Entomoplasmataceae fam. nov., with Mesoplasma gen. nov. as genus II. Recognition of the two proposed new genera for mollicutes of insect and plant origin and the current expectation that these hosts will continue to be a rich source of wall-less prokaryotes suggest that a formal classification at higher taxonomic levels of family and order would provide not only a logical identification scheme but one that would reflect current phylogenetic relationships (49).

Much discussion has taken place about the taxonomic significance of sterol requirements within the class Mollicutes $(10,26)$. The earlier elevation of the acholeplasmas to ordinal rank (12) would seem well justified now but from a phylogenetic or genetic standpoint rather than from that of sterol requirement. Growth in the absence of sterols has not proved to be synapomorphic for any mollicute taxon, because organisms with this characteristic occur in at least three phylogenetic groups (49). In recent proposals for taxonomy of the anaeroplasmas, other factors outweighed sterol requirement at the ordinal and family levels (29). The 
clearly polyphyletic nature of mollicute sterol requirements is reminiscent of the status of genome size in the mollicutes. This character, once highly valued as a marker at higher taxon levels, was later found to be polyphyletic (49) and eventually proved to be variable within genera $(2,24)$. The decreased use of sterol requirement in the higher taxonomy of the mollicutes, the ambiguity in interpretation of tests with Tween 80, and the close phylogenetic position of sterol-requiring and non-sterol-requiring, nonhelical mollicutes from the insect and plant habitats argue against creation of new families on the basis of sterol requirements. Consequently, we propose that members of the sterolrequiring genus Entomoplasma, which cannot grow in the absence of sterols, and members of the genus Mesoplasma, which are able to grow in the presence of $0.04 \%$ Tween 80 , should be placed in a single family. Accordingly, we propose (i) the elevation of the genus Entomoplasma to family rank, Entomoplasmataceae, and (ii) the inclusion of Mesoplasma as a second genus of the proposed new family.

Description of Entomoplasmataceae. (En.to.mo.plas.ma.ta'ce.ae. M.L. neut. n. Entomoplasma, type genus of the family; -aceae ending to denote a family; M.L. fem. pl. n. Entomoplasmataceae, the Entomoplasma family). Cells are usually coccoidal or occur as short, branched or unbranched, pleomorphic, nonhelical filaments. They are filterable through membranes with an average pore diameter of 220 to $450 \mathrm{~nm}$; nonmotile; bounded by a single membrane, with no evidence of a cell wall; and facultatively anaerobic. Colonies on solid medium containing $0.8 \%$ Noble agar usually have a fried-egg appearance. The organisms are chemoorganotrophic. Acid is produced from glucose, with evidence of a phosphoenolpyruvate-dependent sugar transport system(s) in some members. Arginine and urea are not hydrolyzed. Colonies of some species may hemadsorb guinea pig erythrocytes. The organisms may or may not require serum or cholesterol for growth, with growth on serum-free broth medium occurring only in the presence of $0.04 \%$ Tween 80 (polyoxyethylene sorbitan). The temperature range for growth varies from 10 to $37^{\circ} \mathrm{C}$, with the optimum usually at $30^{\circ} \mathrm{C}$. The genome size ranges from 790 to $1,140 \mathrm{kbp}$, with the guanine-plus-cytosine content of the DNA varying from 27 to $30 \mathrm{~mol} \%$. The organisms utilize the UGA codon as a tryptophan signal.

Two genera are accepted in this family: Entomoplasma gen. nov., the type genus, and Mesoplasma gen. nov. Species of Entomoplasma require serum or cholesterol for growth. Species of Mesoplasma cannot grow in serum-free broth medium alone but show sustained growth in serumfree medium containing $0.04 \%$ Tween 80 (polyoxyethylene sorbitan) or in serum-containing medium.

Proposal for elevation of Entomoplasmataceae to ordinal rank (order II, Entomoplasmatales), with Entomoplasmataceae fam. nov. as family I and transfer of family Spiroplasmataceae from order I, Mycoplasmatales, as family II. The proposal to establish two new genera for mollicutes of insect and plant origin and to unite these organisms at a higher taxal level into a separate family still leaves some taxonomic problems for the insect- or plant-derived spiroplasmas unresolved. Currently, sterol-requiring, helical organisms in the genus Spiroplasma are classified within family II, Spiroplasmataceae, order I, Mycoplasmatales. Because 16S rRNA phylogenetic analysis (49) shows that the spiroplasma lineage gave rise to the genera Entomoplasma and Mesoplasma, these genera are most appropriately classified with spiroplasmas. In addition to the phylogenetic evidence, this decision is supported by the biological and ecological significance of moll- icutes in these hosts and evidence that the numbers of mollicutes of these three genera found in insects may reach unprecedented numbers $(4,13,41,50)$.

It should be emphasized that the primary distinction being made concerns cultivable mollicutes that are consistently and evolutionarily associated with insects and plants, as contrasted with the possibly accidental isolation of true Mycoplasma species from plant hosts. In this regard, it should be noted that a strain identified serologically as an equine mycoplasma, Mycoplasma equigenitalium, was isolated from field plants in France (48). The isolate differed from most other known sterol-requiring mollicutes of insect or plant origin in having an optimum growth temperature of $37^{\circ} \mathrm{C}$. In contrast to Mycoplasma species, several classic Acholeplasma species (Acholeplasma axanthum and Acholeplasma oculi) have been found frequently on plant surfaces $(8,39,47)$. Finally, the "mycoplasma-like organisms" that cause many plant diseases (19), although clearly mollicutes (17), should not be easily confused with either entomoplasmas or mesoplasmas because they cannot be cultivated. Thus, characterization of any primary isolate of a nonhelical mollicute of plant or insect origin should first entail an analysis of sterol requirement and then serologic comparison with all established species in the genus Entomoplasma or Mesoplasma, depending on the organism's sterol requirement. If the results are negative, the isolate should then be tested against antisera to either Acholeplasma or Mycoplasma species, again depending on the results of the sterol test.

On the basis of these considerations, we believe it justified on phylogenetic and phenotypic grounds to propose a new order (Entomoplasmatales ord. nov.) within the class Mollicutes for separation of all established culturable nonacholeplasma mollicutes associated with insects and plants (Table 1). Two families are proposed within Entomoplasmatales ord. nov.: family Entomoplasmataceae fam. nov., as proposed above, would consist of two genera, Entomoplasma gen. nov. for sterol-requiring insect or plant mollicutes and Mesoplasma gen. nov. for those non-sterol-requiring organisms capable of sustained growth in serum-free medium supplemented with $0.04 \%$ Tween 80 .

In addition, we propose the transfer of the family Spiroplasmataceae from family II within the Mycoplasmatales to family II of the Entomoplasmatales. The genus Spiroplasma would be retained as genus I within Spiroplasmataceae, and genus and family descriptions for these organisms would remain as previously proposed $(34,51)$. A comparison of the distinguishing properties among members of the order Entomoplasmatales is presented in Table 1.

Description of Entomoplasmatales, order II of class Mollicutes (Edward and Freundt 1967). Entomoplasmatales (En.to.mo.plas.ma.ta'les. M.L. neut. n. Entomoplasma, type genus of the family Entomoplasmataceae; -ales ending to denote an order; M.L. fem. pl. n. Entomoplasmatales, the Entomoplasma order). Cells may be helical or nonhelical. Helical cells are usually 100 to $200 \mathrm{~nm}$ in diameter and 3 to $5 \mu \mathrm{m}$ in length during the logarithmic phase of growth. Cells are motile, with flexional and twisting movements and rotatory directional motility. Flagella, periplasmic fibrils, and cell wall structures are absent. Cells may also occur as nonmotile pleomorphic coccoidal forms $(300$ to $500 \mathrm{~nm}$ in diameter) or short, branched or unbranched filaments, bounded by a single membrane. Cells are filterable through membranes with an average pore diameter of 220 to $450 \mathrm{~nm}$ and are facultatively anaerobic. Nonhelical organisms usually form fried-egg-type colonies on solid medium containing 
$0.8 \%$ Noble agar. Helical organisms usually form diffuse colonies on $0.8 \%$ Noble agar, but fried-egg-type colonies can be seen on solid medium with $2.25 \%$ Noble agar. The cells are chemoorganotrophic. Acid is usually produced from glucose, with evidence that members in both families possess a phosphoenolpyruvate-dependent sugar phosphotransferase system(s). Arginine may or may not be hydrolyzed. There is no hydrolysis of urea. Colonies of some species may hemadsorb guinea pig erythrocytes. Cells may or may not require serum or cholesterol for growth, with growth on serum-free broth medium occurring only in the presence of $0.04 \%$ Tween 80 (polyoxyethylene sorbitan). The temperature range for growth varies from 10 to $43^{\circ} \mathrm{C}$, with the optimum usually at 30 to $32^{\circ} \mathrm{C}$. The genome size ranges from 790 to $2,200 \mathrm{kbp}$, with the guanine-plus-cytosine content of the DNA varying from 24 to $30 \mathrm{~mol} \%$. All organisms tested utilize the UGA codon as a tryptophan signal.

Emended description of Mycoplasmataceae, family I of Mycoplasmatales (Freundt 1955) Razin and Freundt 1984. Cells are nonhelical, varying from pleomorphic coccoidal forms 300 to $850 \mathrm{~nm}$ in diameter to short or long, branched or unbranched filaments 200 to $300 \mathrm{~nm}$ in width to $1,500 \mathrm{~nm}$ in length. Some have specialized terminal structures that mediate attachment to eukaryotic cells. Cells lack a cell wall and are bounded by a single plasma membrane. They are usually nonmotile, but some demonstrate gliding motility. The organisms are facultatively anaerobic, with some species showing growth only under more rigorous anaerobic (but not oxygen-free) environments. They possess a truncated flavin-terminated electron transport chain devoid of quinones and cytochromes. Fermentative species frequently have a phosphoenolpyruvate-dependent sugar-phosphotransferase enzyme system(s). Colonies are small $(1 \mathrm{~mm}$ in diameter) to very small, varying in morphology from uniformly granular types to those with a fried-egg appearance. The organisms are chemoorganotrophs, using either sugars, arginine, or urea as a major energy source. Some species exhibit neither glucose fermentation nor arginine hydrolysis. The cells require cholesterol or a related sterol for growth. Temperature range for growth is 30 to $43^{\circ} \mathrm{C}$, with the optimum usually at $37^{\circ} \mathrm{C}$. Organisms are parasites and pathogens of a wide range of vertebrate hosts. The $\mathrm{G}+\mathrm{C}$ content (in moles percent) of the DNA ranges from 23 to 40 , and the genome size varies from 600 to $1,350 \mathrm{kbp}$. All species examined utilize UGA as a tryptophan codon. The type species is Mycoplasma mycoides (Borrel, Dujardin-Beaumetz, Jeantet, and Jouan 1910) Freundt 1955, 73.

Emended description of Mycoplasmatales, order I of class Mollicutes (Edward and Freundt 1967) Razin and Freundt 1984. The characteristics of the order are as described for the family.

The classification proposed herein permits mollicute taxonomy to be in close accord with phylogenetic concepts. Such a classification is highly desirable, since schemes that do not take phylogeny into account often encounter serious difficulties. Such difficulties surfaced in recent descriptions of new nonhelical mollicutes, in that insect- or plant-derived strains with the ability to grow without sterols, but in the presence of $0.04 \%$ Tween 80 , were referred, of necessity, to the genus Acholeplasma. When the phylogenetic studies of Weisburg and colleagues (49) had been completed, it was evident that the insect and plant strains of non-sterolrequiring organisms belonged to an entirely different phylogenetic cluster than classic acholeplasmas. It therefore came as no surprise that the insect and plant organisms differed from classical acholeplasmas not only in their ability to grow in Tween 80-supplemented media but also in their genome sizes, in their usage of the UGA codon, and in their possession of a component (enzyme II) of a phosphoenolpyruvate-dependent sugar transport system. Transfer of these organisms from Acholeplasma was therefore clearly mandated (15).

The most straightforward means of altering mollicute taxonomy to accommodate these new organisms is to adopt a classification scheme that is congruent with the phylogeny proposed by Weisburg and colleagues (49). In that study (Fig. 1), all cultivable arthropod-associated mollicutes (other than classical acholeplasmas) clustered together. Ten Spiroplasma species, all from insects or ticks, clustered together to form a monophyletic group. A second monophyletic group, consisting of eight nonhelical species, branched from the spiroplasma lineage. This cluster contained five insect and plant organisms. Our proposal retains the previous designation of the helical organisms as members of a family Spiroplasmataceae but proposes a new family, Entomoplasmataceae, to comprise the five nonhelical organisms, four similar organisms not studied phylogenetically, and a large number of putative species still under study. These organisms differ from members of the Spiroplasmataceae not only in lacking helicity but also in having smaller genomes. There is, at present, a conspicuous difference in the upper limits of temperature tolerance of the two families, since some spiroplasmas grow at $41^{\circ} \mathrm{C}$, or even at $43^{\circ} \mathrm{C}(16)$. Also, Mesoplasma species placed phylogenetically in this group have no sterol requirement for growth. All of the proposed members of the new family that were studied phylogenetically shared 22 nonrestrictive sequence signatures with members of the Spiroplasma apis clade (49).

We hope that the underlying metabolic or biophysical mechanisms involved in the ability of mesoplasmas to grow in the presence of Tween 80 will be elucidated in the near future. Analyses of batches of Tween 80 used for these studies have shown that the level of possible sterol contamination of the Tween 80 supplement was well below a substrate level (46). Although it is still possible that the contribution of Tween 80 to mesoplasma growth could involve its fatty acid components, supplementation with pure fatty acids such as oleic acid did not produce the desired effect. Growth promotion by the low levels of Tween 80 provided in our studies suggests that this detergent might function by structural or chemical alterations of the cell membrane, rather than by supplying some necessary fatty acid components.

At present, the main properties delineating members of the genus Entomoplasma are their sterol requirement (including failure to grow in the presence of Tween 80), an optimum growth temperature of $30^{\circ} \mathrm{C}$, their relatively low temperature maxima, their nonhelicity, their small genome, and their association with arthropods. Their arthropod association forms a common link with the mesoplasmas and spiroplasmas and provides a rational basis for their classification at the ordinal and family levels. Host association is a commonly used character in prokaryote taxonomy. Although most frequently used to classify organisms at the species level, it is not infrequently used at the genus level. The use of the character at the ordinal level is less common, but not unique, even in the class Mollicutes. The order Anaeroplasmatales is confined entirely to bovine and/or ovine hosts and is in fact confined to the rumens of those species. The order Mycoplasmatales, as herein defined, is confined entirely to vertebrate animals. The coherence of these associations confirms the well-known principle that 


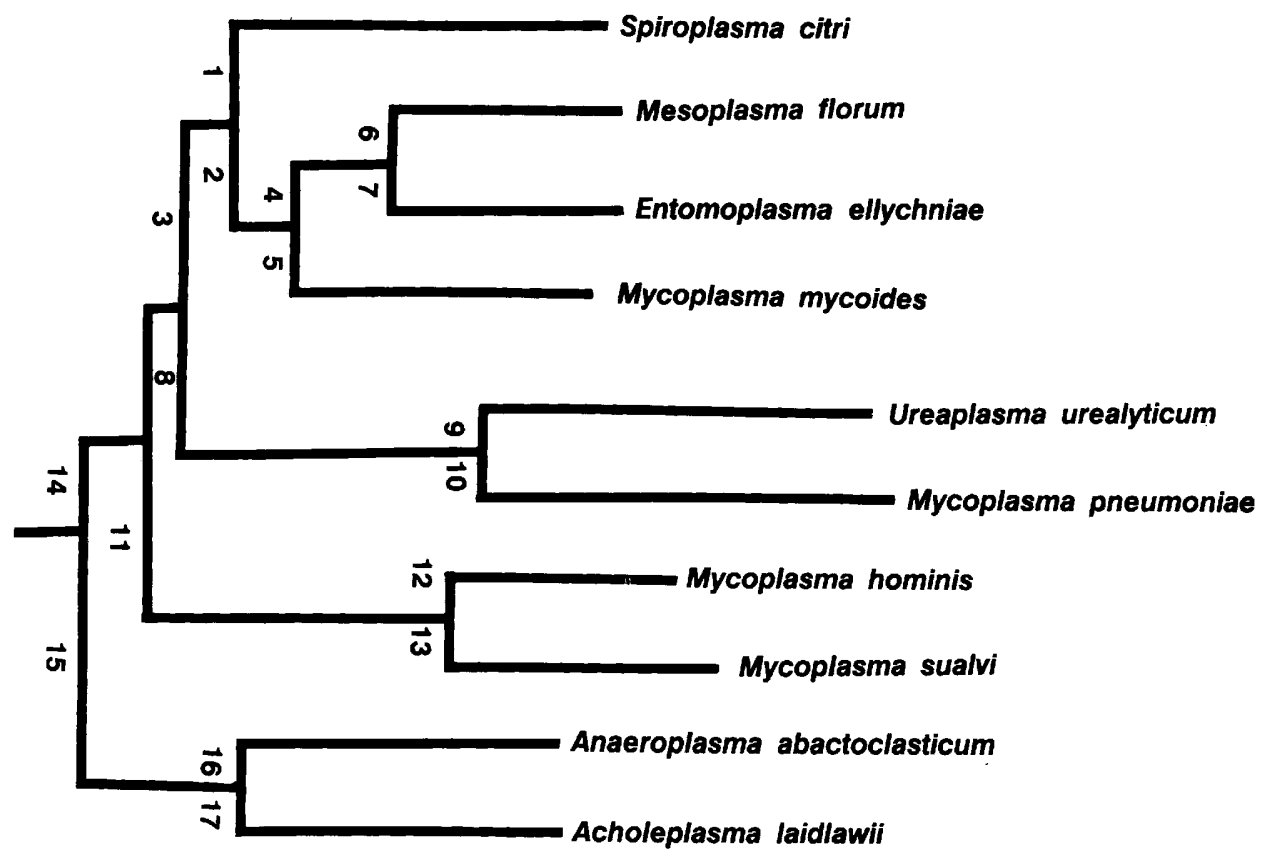

FIG. 1. Phylogenetic basis for proposed amended classification. The dendrogram is modified from Weisburg et al. (49); branch lengths are diagrammatic. Numerals in the following refer to those in the dendrogram. The proposed genera Entomoplasma gen. nov., 7, and Mesoplasma gen. nov., 6, are placed in the family Entomoplasmataceae fam. nov., 4. Species of the genus Spiroplasma, 1, are assigned to the family Spiroplasmataceae and are placed with the family Entomoplasmataceae in the proposed order Entomoplasmatales ord. nov., 3. Species of the order Mycoplasmatales, 8 and 11, including the mycoides cluster, 5, are retained in the family Mycoplasmataceae, but these higher taxa are redescribed herein. The Mycoplasma pneumoniae, 10; Mycoplasma hominis, 12; and Mycoplasma sualvi, 13, clusters are as previously given (49). Although some species of Mycoplasma that have not been studied phylogenetically can be assigned to clusters on the basis of phenotypic markers, many cannot be so assigned. The genus Ureaplasma, 9, is most closely related to the M. pneumoniae cluster. Three species of Mycoplasma, including Mycoplasma mycoides, 5, are related phylogenetically to the family Entomoplasmataceae but cannot be transferred to the genus Entomoplasma because Mycoplasma mycoides is the type species of the genus Mycoplasma and of corresponding higher taxa. The polyphyly of the genus Mycoplasma is apparent from the detailed phylogenies of spiroplasmas and mycoplasmas (49). A primitive lineage of mollicutes includes the orders Anaeroplasmatales, 17, and Acholeplasmatales, 17. The genus Asteroleplasma has not been placed in this dendrogram because phylogenetic information concerning it was ambiguous (49). Recent phylogenetic studies (16) place the noncultivable "mycoplasma-like organisms" near the order Acholeplasmatales.

close association of parasites with their hosts creates evolutionary "dead ends," which make broad host transfers infrequent or impossible. The phylogenetic evidence (49) supporting retention of host affinities in the case of the mollicutes is overwhelming. All 15 of the arthropod-associated organisms clustered together, and 21 vertebrate $\mathrm{Myco}$ plasma species clustered in a sister group. Because the phylogenetic rationale for the classification system proposed here is so robust, we anticipate that a number of additional phenotypic characters will emerge to assist in determination of emerging isolates.

From a phylogenetic point of view, the one anomaly created by the proposed classification is the retention of a group of three Mycoplasma species (Mycoplasma mycoides, Mycoplasma capricolum, and Mycoplasma putrefaciens) in the family Mycoplasmataceae. The phylogenetic studies (49) showed that this group is closely tied to the family Entomoplasmataceae. There have been a few reports of arthropod association involving members of this group $(6,7,23$, 33). Although there is no evidence at present that these mollicutes are natural inhabitants of the host arthropods, the suggestion of an arthropod link is intriguing. A host transfer from arthropods is the most likely route by which the mollicutes colonized vertebrates evolutionarily. From a taxonomic point of view, a phylogenetic classification of $\mathrm{Myco}$ plasma mycoides and its close allies is impossible, since this species is the type species for the genus and for its family and order. Also, because this species and some of its cohorts are of considerable importance in veterinary medicine, a name change at the generic level would be unwelcome. Furthermore, although serologic evidence suggests that other phenotypic characters might be found to separate the mycoides group from other Mycoplasma species, none are available at this time. Finally, the alternative of renaming all Mycoplasma species not assigned to the mycoides cluster, which could involve more than 85 species, would be as unthinkable as the renaming of Mycoplasma mycoides. It is, therefore, clear that the genus Mycoplasma must remain polyphyletic at this time $(14,15)$.

We are greatly indebted to members of the International Committee on Systematic Bacteriology Subcommittee on the Taxonomy of Mollicutes for their stimulating and helpful criticisms and advice provided during the formulation of the ideas in this presentation and during the preparation of the manuscript.

\section{REFERENCES}

1. Bonnet, F., C. Saillard, J. C. Vignault, M. Garnier, P. Carle, J. M. Bové, D. L. Rose, J. G. Tully, and R. F. Whitcomb. 1991. Acholeplasma seiffertii sp. nov., a mollicute from plant surfaces. Int. J. Syst. Bacteriol. 41:45-49.

2. Carle, P., D. L. Rose, J. G. Tully, and J. M. Bové. 1992. The genome size of spiroplasmas and other mollicutes. Proc. 9th Int. 
Congr. Int. Org. Mycoplasmol. IOM Lett. 2:263.

3. Cirillo, V. P., and S. Razin. 1973. Distribution of a phosphoenolpyruvate-dependent sugar phosphotransferase system in mycoplasmas. J. Bacteriol. 113:212-217.

4. Clark, T. B., and K. J. Hackett. 1989. Ecology of spiroplasmas, p. 113-200. In R. F. Whitcomb and J. G. Tully (ed.), The mycoplasmas, vol. V. Academic Press, New York.

5. Clark, T. B., J. G. Tully, D. L. Rose, R. Henegar, and R. F. Whitcomb. 1986. Acholeplasmas and similar nonsterol-requiring mollicutes from insects: missing link in microbial ecology. Curr. Microbiol. 12:9-11.

6. Cottew, G. S., and F. R. Yeats. 1982. Mycoplasmas and mites in the ears of clinically normal goats. Aust. J. Vet. Sci. 59:77-81.

7. DaMassa, A. J., and D. L. Brooks. 1991. The external ear canal of goats and other animals as a mycoplasma habitat. Small Ruminant Res. 4:85-93.

8. Eden-Green, S., and J. G. Tully. 1979. Isolation of Acholeplasma spp. from coconut palms affected by lethal yellowing disease in Jamaica. Curr. Microbiol. 2:311-316.

9. Edward, D. G. ff., and E. A. Freundt. 1967. Proposal for Mollicutes as name of the class established for the order Mycoplasmatales. Int. J. Syst. Bacteriol. 17:267-268.

10. Edward, D. G. ff., and E. A. Freundt. 1970. Amended nomenclature for strains related to Mycoplasma laidlawii. J. Gen. Microbiol. 62:1-2.

11. Freundt, E. A. 1955. The classification of the pleuropneumonia group of organisms (Borrelomycetales). Int. Bull. Bacteriol. Nomencl. Taxon. 5:67-78.

12. Freundt, E. A., R. F. Whitcomb, M. F. Barile, S. Razin, and J. G. Tully. 1984. Proposal for elevation of the family Acholeplasmataceae to ordinal rank: Acholeplasmatales. Int. J. Syst. Bacteriol. 34:346-349.

13. Hackett, K. J., R. F. Whitcomb, J. G. Tully, J. E. Lloyd, J. J. Anderson, T. B. Clark, R. B. Henegar, D. L. Rose, E. A. Clark, and J. L. Vaughn. 1992. Lampyridae (Coleoptera): a plethora of mollicute associations. Microb. Ecol. 23:181-193.

14. International Committee on Systematic Bacteriology Subcommittee on the Taxonomy of Mollicutes. 1990. Minutes of the interim meeting, 7 and 8 July 1990, Istanbul, Turkey. Int. J. Syst. Bacteriol. 41:333-336.

15. International Committee on Systematic Bacteriology Subcommittee on the Taxonomy of Mollicutes. 1993. Minutes of the interim meetings, 1 and 2 August 1992, Ames, Iowa. Int. J. Syst. Bacteriol. 43:394-397.

16. Konai, M., E. A. Clark, and R. F. Whitcomb. 1992. Temperature ranges and optima of spiroplasmas. Proc. 9th Int. Congr. Int. Org. Mycoplasmol. IOM Lett. 2:137.

17. Lim, P.-O., and B. B. Sears. 1992. Evolutionary relationships of a plant-pathogenic mycoplasmalike organism and Acholeplasma laidlawii deduced from two ribosomal protein gene sequences. J. Bacteriol. 174:2606-2611.

18. McCoy, R. E., H. G. Basham, J. G. Tully, D. L. Rose, P. Carle, and J. M. Bové. 1984. Acholeplasma florum, a new species isolated from plants. Int. J. Syst. Bacteriol. 34:11-15.

19. McCoy, R. E., A. Caudwell, C. J. Chang, T. A. Chen, L. N. Chiykowski, M. T. Cousin, J. L. Dale, G. T. N. de Leeuw, D. A. Golino, K. J. Hackett, B. C. Kirkpatrick, R. Marwitz, H. Petzold, R. C. Sinha, M. Sugiura, R. F. Whitcomb, I. L. Yang, B. M. Zhu, and E. Seemüller. 1989. Plant diseases associated with mycoplasma-like organisms, p. 545-640. In R. F. Whitcomb and J. G. Tully (ed.), The mycoplasmas, vol. V. Academic Press, New York.

20. McCoy, R. E., D. S. Williams, and D. L. Thomas. 1979. Isolation of mycoplasmas from flowers, p. 75-80. In R. E. McCoy and H. Su (ed.), Mycoplasma disease of plants. Republic of China/ United States Cooperative Science Seminar, National Science Council, Taipei, Republic of China.

21. Navas-Castillo, J., F. Laigret, A. Hocquellet, C. J. Chang, and J. M. Bové. Evidence for a phosphoenolpyruvate-dependent sugar-phosphotransferase system in the mollicute Acholeplasma florum. Biochimie, in press.

22. Navas-Castillo, J., F. Laigret, J. G. Tully, and J. M. Bové. 1992. Le mollicute Acholeplasma florum possede un gene du systeme phosphoenolpyruvate sucre-phosphotransferase et il utilise UGA comme codon tryptophane. C.R. Acad. Sci. (Paris) 315: 43-48.

23. Nayak, N. C., and M. K. Bhowmik. 1990. Goat flea (order Siphonaptera) as a possible vector for the transmission of caprine mycoplasmal polyarthritis with septicemia. Prev. Vet. Med. 9:259-266.

24. Neimark, H. C., and C. S. Lange. 1990. Pulse-field electrophoresis indicates full-length mycoplasma chromosomes range widely in size. Nucleic Acids Res. 18:5443-5448.

25. Neimark, H. C., J. G. Tully, D. Rose, and C. Lange. 1992. Chromosome size polymorphism among mollicutes. Proc. 9th Int. Congr. Int. Org. Mycoplasmol. IOM Lett. 2:261.

26. Razin, S., and E. A. Freundt. 1984. Class I. Mollicutes Edward and Freundt 1967, 267 ${ }^{\mathrm{AL}}$; Order I. Mycoplasmatales Freundt 1955, 71 AL, p. 740-742. In N. R. Krieg and J. G. Holt. (ed.), Bergey's manual of systematic bacteriology, vol. 1. Williams \& Wilkins, Baltimore.

27. Renaudin, J., M. C. Pascarel, C. Saillard, C. Chevalier, and J. M. Bové. 1986. Chez les spiroplasmes le codon UGA n'est pas non sens mais semble coder pour le tryptophane. C.R. Acad. Sci. (Paris) 303:539-540.

28. Robertson, J. A., L. E. Pyle, G. W. Stemke, and L. R. Finch. 1990. Human ureaplasmas show diverse genome sizes by pulsed-field electrophoresis. Nucleic Acids. Res. 18:1451-1456.

29. Robinson, I. M., and E. A. Freundt. 1987. Proposal for an amended classification of anaerobic mollicutes. Int. J. Syst. Bacteriol. 37:78-81.

30. Rose, D. L., J. P. Kocka, N. L. Somerson, J. G. Tully, R. F. Whitcomb, P. Carle, J. M. Bové, D. E. Colflesh, and D. L. Williamson. 1990. Mycoplasma lactucae sp. nov., a sterolrequiring mollicute from a plant surface. Int. J. Syst. Bacteriol. 40:138-142.

31. Rose, D. L., J. G. Tully, J. M. Bové, and R. F. Whitcomb. 1992. A modified test for determination of sterol and fatty acid requirements of mollicutes. Proc. 9th Int. Congr. Int. Org. Mycoplasmol. IOM Lett. 2:232.

32. Saglio, P., M. Lhospital, D. Laffèche, G. Dupont, J. M. Bové, J. G. Tully, and E. A. Freundt. 1973. Spiroplasma citri gen. and sp. n.: a mycoplasma-like organism associated with "stubborn" disease of citrus. Int. J. Syst. Bacteriol. 23:191-204.

33. Shifrine, M., K. P. Bailey, and S. S. Stone. 1972. Contagious bovine pleuropneumonia: isolation of Mycoplasma mycoides var. mycoides from ticks collected from infected cattle and infection attempts using these ticks. Bull. Epizoot. Dis. Afr. 20(Sp. issue): $43-45$.

34. Skripal, I. G. 1983. Revival of the name Spiroplasmataceae fam. nov., nom. rev., omitted from the 1980 approved lists of bacterial names. Int. J. Syst. Bacteriol. 33:408.

35. Somerson, N. L., J. P. Kocka, R. A. Del Giudice, and D. L. Rose. 1982. Isolation of acholeplasmas and a mycoplasma from vegetables. Appl. Environ. Microbiol. 43:412-417.

36. Tanaka, R., A. Muto, and S. Osawa. 1989. Nucleotide sequence of tryptophan tRNA gene in Acholeplasma laidlawii. Nucleic Acids Res. 17:5842.

37. Tarshis, M. A. 1991 . Spiroplasma cells utilize carbohydrates via the phosphoenolpyruvate-dependent sugar phosphotransferase system. Can. J. Microbiol. 37:477-479.

38. Tarshis, M. A., V. L. Migoushina, and L. F. Panchenko. 1973. On the phosphorylation of sugars in Acholeplasma laidlawii. FEBS Lett. 31:111-113.

39. Tully, J. G. 1979. Special features of the acholeplasmas, p. 431-449. In M. F. Barile and S. Razin (ed.), The mycoplasmas, vol. I. Academic Press, New York.

40. Tully, J. G. 1983. Reflections on recovery of some fastidious mollicutes with implications of the changing host patterns of these organisms. Yale J. Biol. Med. 56:799-813.

41. Tully, J. G. 1989. Class Mollicutes: new perspectives from plant and arthropod studies, p. 1-31. In R. F. Whitcomb and J. G. Tully, (ed.), The mycoplasmas, vol. V. Academic Press, New York.

42. Tully, J. G., D. L. Rose, P. Carle, J. M. Bové, K. J. Hackett, and R. F. Whitcomb. 1988. Acholeplasma entomophilum sp. nov. 
from gut contents of a wide range of host insects. Int. J. Syst. Bacteriol. 38:164-167.

43. Tully, J. G., D. L. Rose, E. Clark, P. Carle, J. M. Bové, R. B. Henegar, R. F. Whitcomb, D. E. Colflesh, and D. L. Williamson. 1987. Revised group classification of the genus Spiroplasma (class Mollicutes), with proposed new groups XII to XXIII. Int. J. Syst. Bacteriol. 37:357-364.

44. Tully, J. G., D. L. Rose, K. J. Hackett, R. F. Whitcomb, P. Carle, J. M. Bové, D. E. Colflesh, and D. L. Williamson. 1989. Mycoplasma ellychniae sp. nov., a sterol-requiring mollicute from the firefly beetle Ellychnia corrusca. Int. J. Syst. Bacteriol. 39:284-289.

45. Tully, J. G., D. L. Rose, R. E. McCoy, P. Carle, J. M. Bové, R. F. Whitcomb, and W. G. Weisburg. 1990. Mycoplasma melaleucae sp. nov., a sterol-requiring mollicute from flowers of several tropical plants. Int. J. Syst. Bacteriol. 40:143-147.

46. Tully, J. G., D. L. Rose, and J. E. Oliver. Unpublished studies.

47. Tully, J. G., R. F. Whitcomb, D. L. Rose, K. J. Hackett, E. Clark, R. B. Henegar, P. Carle, and J. M. Bové. 1990. Current insight into the host diversity of acholeplasmas. Zentralbl. Bakteriol. (Suppl. 20)461-467.

48. Vignault, J. C., C. Saillard, P. Carle, J. M. Bové, D. L. Rose, and J. G. Tully. Unpublished studies.

49. Weisburg, W. G., J. G. Tully, D. L. Rose, J. P. Petzel, H. Oyaizu, D. Yang, L. Mandelco, J. Sechrest, T. G. Lawrence, J. Van Etten, J. Maniloff, and C. R. Woese. 1989. A phylogenetic analysis of the mycoplasmas: basis for their classification. J.
Bacteriol. 171:6455-6467.

50. Whitcomb, R. F., and K. J. Hackett. 1989. Why are there so many species of mollicutes? An essay on prokaryote diversity, p. 205-240. In L. Knutson and A. K. Stoner (ed.), Biotic diversity and germplasm preservation, a global imperative. Beltsville Symposium in Agricultural Research, vol. 13. Kluwer Academic Publishers, Boston.

51. Whitcomb, R. F., and J. G. Tully. 1984. Family III. Spiroplasmataceae Skripal 1983, 408 ${ }^{\mathrm{VP}}$. Genus I. Spiroplasma Saglio, L'hospital, Laflèche, Dupont, Bové, Tully and Freundt 1973, $191^{\mathrm{AL}}$, p. 781-787. In N. R. Krieg and J. G. Holt (ed.), Bergey's manual of systematic bacteriology, vol. 1. Williams \& Wilkins, Baltimore.

52. Williamson, D. L., J. G. Tully, D. L. Rose, K. J. Hackett, R. Henegar, P. Carle, J. M. Bové, D. E. Colflesh, and R. F. Whitcomb. 1990. Mycoplasma somnilux sp. nov., Mycoplasma luminosum sp. nov., and Mycoplasma lucivorax sp. nov., new sterol-requiring mollicutes from firefly beetles (Coleoptera: Lampyridae). Int. J. Syst. Bacteriol. 40:160-164.

53. Williamson, D. L., J. G. Tully, and R. F. Whitcomb. 1989. The genus Spiroplasma, p. 71-111. In R. F. Whitcomb and J. G. Tully (ed.), The mycoplasmas, vol. V. Academic Press, New York.

54. Yamao, F., A. Muto, Y. Kawauchi, M. Iwami, S. Iwagami, Y. Azumi, and S. Osawa. 1985. UGA is read as tryptophan in Mycoplasma capricolum. Proc. Natl. Acad. Sci. USA 82:23062309. 